ユーロピウムの抽出量㧍上び水相中の水素イオン濃度の 増加量は一定となった.これらの值は試料溶液中の塩酸 初濃度の影響をうけ，塩酸濃度の堌加とともにそれぞれ の值恃直楾的に減少した. そしてこのときの $\Delta\left[\mathrm{H}^{+}\right]$水相 $[\mathrm{Eu}]$ 有機相 の比は希薄溶液のときの值 3.0 上り小さく 2.6〜2.8 であった.

これより従来の希薄溶液の抽出平衡とは異なった平衡 系が関与し，(1）式以外にほかの抽出機構も存在しうる ことが推定された。

\section{文韵}

1) Y. Marcus, A.S. Kertes, "Ion Exchange and Solvent Extraction of Metal Complex", p. 538 (1969). Wiley Interscience., London.

2) S.G.K. Nair, M. Smutz, J. Inorg. Nucl, Chem. 29, 1787 (1967).

3) T.G. Lentz, M. Smutz, ibid. 30, 621 (1968).

4) T. Goto, M. Smutz, J. Nucl. Sci. Tech. 2, 410 (1965).

5) T. Goto, ibid. 6, 63 (1969).

6）瑥川二朗，松本 昭，高过和彦，森藤定昭，平島克享，工化 $74 ， 14$ (1971).

7）塭川二朗，松本 昭，森藤定昭，本誌 39，254（1971）

8) G.R. Choppin, P.J. Unrein, J. Inorg. Nucl. Chem. 25, 387 (1963).

\title{
Research Paper
}

\section{溶融塩を用いたリチウム合金-塭素二次電池の可能性とその基礎研究*}

\author{
吉 沢 四 郎**, 竹 原善一 郎** \\ 伊藤 靖 彦**, 森 本 信 吾**
}

\section{Basic Studies on a Lithium Alloys-Chlorine Secondary Battery using Molten Salt as the Electrolyte}

\author{
Shiro YoshIzAwa, Zenichi ro TAKEHARA, \\ Yasuhiko ITO and Shingo MORIMOTO \\ (Department of Industrial Chemistry, Faculty of Engineering,
Kyoto University, Yoshida, Kyoto
}

A new type of secondary battery composed of

$\ominus \mathrm{Li}-\mathrm{Metal}(\mathrm{Zn}, \mathrm{Sn}$, or $\mathrm{Pb}) / \mathrm{LiCl}-\mathrm{KCl}$ molten salt/carbon-chlorine $\oplus$

system was constructed to determine its feasibility as an automobile battery experimentally. The liquid alloy of $\mathrm{Li}$ and other metals was used instead of using pure metalic $\mathrm{Li}$ as the active mass for the anode, and because of its high density it occupied a position beneath the molten salt. As an example, when $\mathrm{Zn}$ is used as the alloying metal, the following electrochemical reactions occur;

Overall reaction is then

$$
\begin{aligned}
& \text { positive electrode; } \mathrm{Cl}^{-} \underset{\text { discharge }}{\stackrel{\text { charge }}{\rightleftarrows}} 1 / 2 \mathrm{Cl}_{2}(\mathrm{C})+e^{-} \\
& \text {negative electrode; } \mathrm{Li}^{+}, \mathrm{K}^{+}+\mathrm{Zn}+e^{-} \underset{\text { charge }}{\stackrel{\text { discharge }}{\rightleftarrows}} \mathrm{Li}, \mathrm{K}(\mathrm{Zn})
\end{aligned}
$$

$$
\mathrm{Li}^{+}, \mathrm{K}^{+}+\mathrm{Cl}^{-}+\mathrm{Zn} \underset{\text { discharge }}{\stackrel{\text { charge }}{\rightleftarrows}} \mathrm{Li}, \mathrm{K}(\mathrm{Zn})+1 / 2 \mathrm{Cl}_{2}(\mathrm{C})
$$

In this case, the electromotive force is somewhat less than that in a conventional $\mathrm{Li}-\mathrm{Cl}_{2}$ battery, but cell structure is much simpler and the operating temperature much lower $\left(450^{\circ} \mathrm{C}\right.$ as compared to 614 ${ }^{\circ} \mathrm{C}$ ). The output energy density of the anode is about $130 \mathrm{~W} / \mathrm{kg}$, and the self discharge rate of this cell is about $1.2 \times 10^{-5} \mathrm{~A} / \mathrm{cm}^{2}$ - a negligible value — leading to the conclusion that this type of secondary battery is very promising for automotive use.

\footnotetext{
* リチウム合金-塭素二次電池に関する研究（第 1 報) Studies on the Lithium Alloys-Chlorine Secondary Battery (Part 1) 昭和43年11月 第 9 回電池刢論会 (大阪) 汇て発表

** 京都大学工学部 (京都市左京区吉田本町)
} 


\section{1 緒言 (Introduction)}

電気自動車用電池として単位重量および容積当りの出 力, エネルギー密度の大きい電池の開発が要望され, そ の 1 つとして，リチウム-塩素二次電池が 注目されてい る. 現在, 検討されている電池は負極活物質にりチウ ム, 正極活物翼に塩素を用い, 電解浴に塩化リチウム溶 融塩を用いる形式のものである"。この形式の電池では,

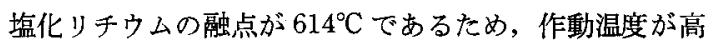
くなり,リチウムの高い反応性と相まって, 電極材料, 容器などに制約を生じ，また自己放電も大きくなる。さ らにリチウムの密度が浴の密度よりも小さいため, 負極 を電池下部に設置する場合はリチウムの保持のための多 孔体が必要となり，また金属霧を生ずる危険がある. 負 極を電池上部化設置する場合は正極である塩索極の配置 に制約を伴う．そこで，電解浴として塩化りチウム一塩 化カリウム混合塩を用い, 作動温度を $450^{\circ} \mathrm{C}$ 前後まで 下げ，負極に亜鉛，スズ，鉛などとリチウムとの合金を 用い,リチウムの活性を下げると同時に負極の密度を高 くし, 負極を電池下部に設置する方式の次の電池を考案 した.

అリチウムー金属（亜鉛，スズ，鉛など）!

塩化りチウム-塩化カリウム|炭素-塩素 $\oplus$

本研究では, この形式の電池の可能性, 充放電特性な どについて検討する。

\section{2 充放電における反応}

(Reaction at Charge and Discharge)

溶融状態にある塩化リチウム一塩化カリウム混合塩を 炭素を陽極, 液体金属（亜鉛，スズ，鉛など）を陰極と して電解すると，陽極からは塩素が発生し，陰極にはり チウム，カリウムが析出し，アルカリ金属合金を形成す る.これがこの形式の電池の充電反応である. 一方, 陽 極で発生した塩素を陰極還元し, 陰極で形成されたアル カリ金属合金を陽極酸化すると，それぞれ，塩素イオン およびリチウムイオン, カリウムイオンを生じ, 元の状 態にもどる.これがこの形式の電池の放電反応である. この場合, 炭素-塩素極が電池の正極, アルカリ金属合 金極が電池の負極となるしたがってこの形式の電池の 正負両極での充放電反忘は液体金属として带鉛を用いた 場合

$$
\text { 正極 }: \mathrm{Cl}^{-} \underset{\text { 放雵 }}{\stackrel{\text { 電 }}{\longrightarrow}} 1 / 2 \mathrm{Cl}_{2}(\mathrm{C})+e^{-}
$$

$$
\text { 負極 }: \mathrm{Li}^{+}, \mathrm{K}^{+}+\mathrm{Zn}+e^{-} \underset{\text { 忘電 }}{\stackrel{\text { 故電 }}{L}} \mathrm{Li}, \mathrm{K}(\mathrm{Zn})
$$

全反応性

$$
\mathrm{Li}^{+}, \mathrm{K}^{+}+\mathrm{Cl}^{-}+\mathrm{Zn} \underset{\text { 放電 }}{\stackrel{\text { 曹 }}{\rightleftarrows}} \mathrm{Li}, \mathrm{K}(\mathrm{Zn})+1 / 2 \mathrm{Cl}_{2}(\mathrm{C})
$$

のようになる.この形式の電池の可能性, 充放電特性を 検討するには正, 負両極での充放電特性, 電解質中での 充放電時のオーム損をそれぞれ別個に検討し，それらを 総合して考察すればよい，正極および電解質の特性に関 しては, すでに著者らが, 溶融金属陰極法による塩化水 素からの塩素の 回収における陽極反応 (充電特性) ${ }^{2)}$ 打 よび高温型塩素一水素然料電池における塩素極での反応 (放電特性) にったいて詳細な検討を加えているので，こ こでは, 負極の充放電特性についてのみ検討し，いまま で得た結果をこれに加味して考察を行う.

\section{3 実験方法 (Experimental Method)}

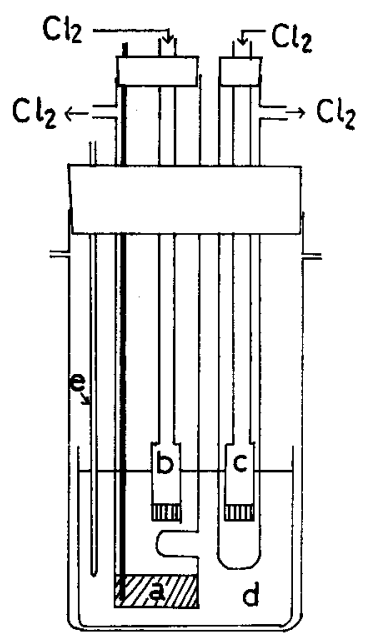
a : $\mathrm{Li}(\mathrm{M}) / \mathrm{Li}^{+}$electrode $(\mathrm{M}: \mathrm{Zn}, \mathrm{Sn}$ or $\mathrm{Pb}$ )
b : $\mathrm{Cl}_{2} / \mathrm{Cl}^{-}$electrode (counter electrode)
c : $\mathrm{Cl}_{2} / \mathrm{Cl}^{-}$electrode (reference electrode)
d : Electrolyte ( $\mathrm{LiCl}-\mathrm{KCl}$ melt)
e : Thermocouple

Fig. 1 Experimental cell

負極の充放電特性を調べるための装置の概略を Fig. 1 に示した．電解ソウ, 容器および電極ホルダーはいずれ もパイレックスガラスでできている. 電解質は $\mathrm{LiCl}$ $\mathrm{KCl}$ 混合塩からなり，その組成は共融組成に近く, $\mathrm{LiCl}$ $58 \mathrm{~mol} \%, \mathrm{KCl} 42 \mathrm{~mol} \%$ かからり融点は約 $352^{\circ} \mathrm{C}$ であ る.この混合塩を十分に混和したのち, ルツボに入れ, アルゴンふんい気中で $450^{\circ} \mathrm{C} に し$, 塩が溶融した後, 塩 素を約 1 時間通気して脱水し, 続いてアルゴンを通気し て, 溶存塩素を除き, 使用に供した。内径 $18 \mathrm{~mm}$ (電極 表面積約 $2.5 \mathrm{~cm}^{2}$ ) のパイレックスガラス製の管の底部 に負極液体金属を $0.1 \mathrm{~g}$ 原子入れ，磁製管で被覆したス テンレス鋼製棒リードをとり，電極とした，相手極，照 合極はいずれも黒鉛製導管の先端に多孔質炭素を取り付 けた電極に塩素を通気する形式の塩素極を用いた。

定電流装置を用い，定電流密度で陰極還元 (充電) し 
たときの電位の時間変化を照合極に対して測定し，また 一定量充電したのち, 定電流密度で陽極酸化（放電）し たときの電位の時間変化を同様に測定した.さらにイン タラプター法により，電極・照合極間のオーム損を測定 し，測定值に補正を加えた．合金の組成変化により平衡 電位が変化していくため, 峳密に定常的な電流密度と電 位との関倸線図を求めることができない，そこでこここ

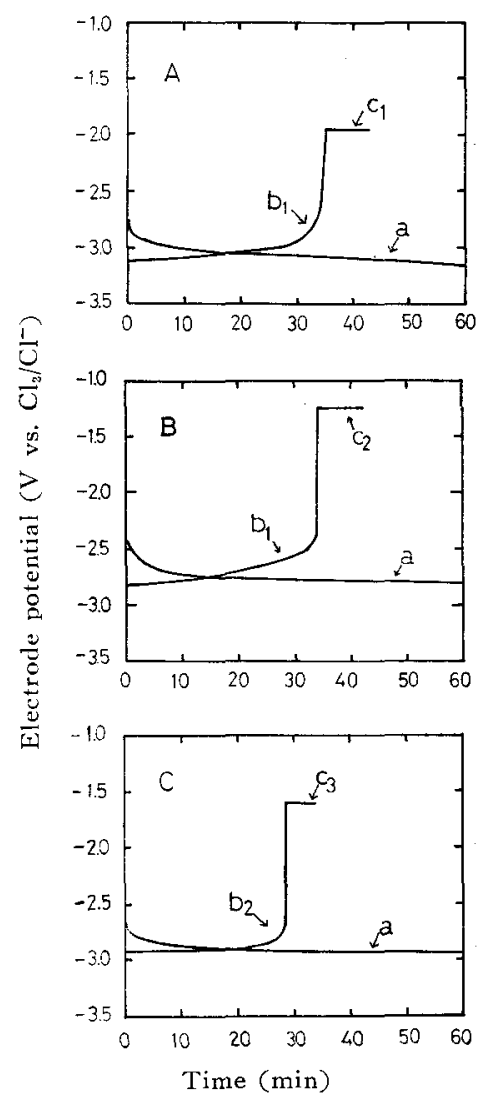

a : Charge at $0.08 \mathrm{~A} / \mathrm{cm}^{2}$ from metal $(\mathrm{Zn}$, $\mathrm{Sn}, \mathrm{Pb}$ )

$\mathrm{b}$ : Discharge from metal-Li, $\mathrm{K}$ alloy after charge of $0.08 \mathrm{~A} / \mathrm{cm}^{2}, 60 \mathrm{~min}$.

$\left(b_{1}\right.$ : current density $0.12 \mathrm{~A} / \mathrm{cm}^{2}, b_{2}$ : $0.16 \mathrm{~A} / \mathrm{cm}^{2}$ )

c : Polarization for ionization of metal $\left(\mathrm{C}_{1}: \mathrm{Zn}, \mathrm{C}_{2}: \mathrm{Sn}, \mathrm{C}_{3}: \mathrm{Pb}\right)$

$A:$ In the case of using $\mathrm{Zn}-\mathrm{Li}, \mathrm{K}$ alloy as negative electrode

$B$ : In the case of using $\mathrm{Sn}-\mathrm{Li}, \mathrm{K}$ alloy as negative electrode

$\mathrm{C}:$ In the case of using $\mathrm{Pb}-\mathrm{Li}, \mathrm{K}$ alloy as negative electrode

Fig. 2 Polarization charactristics at constant current charge and discharge of the negative electrode in $\mathrm{LiCl}-\mathrm{KCl}$ melt at $450^{\circ} \mathrm{C}$
では便宜上一定組成の合金を用い，定電流密度で陰，陽 分極したのち, 数 $\min$ 後に得られる定常電位を測定し, これより電流密度と電位との関係線図を求めた。この状 態でほぼ分極は定常值に達していると考えられる. 負極 液体金属の自己放電速度は Fig. 1 の装置で, 塩素ふん い気とし，一定組成の合金を種々の時間放置したのち， これを定電流密度で基体金属の放電電位になるまで陽極 酸化し，その後さらに順次低い定電流密度で同様な状態 まで陽極酸化するといら方法を適用し, 得られる電気量 の積分值より残存アルカリ金属量を求めることにより測 定した：また充電時生成する負極合金の成分は JACO 発光分光分析器を用い発光分光分析により求めた.

4 結果および考察 (Results and Discussion)

\section{1 負極の定電流充放電曲線}

種々の液体金属を基体金属として用いた場合の負極の 定電流充放電曲線の代表例を Fig. 2 に示した. 充電電 流密度 $0.08 \mathrm{~A} / \mathrm{cm}^{2}$ の場合を示したが，いずれの金属を 用いた場合もこの程度の充電電流密度では大きい電位変 化を伴わずに充電できることがわかる．放電の場合も同 様に大きい電位変化を伴わないで放電でき, 放電が終る とFig. 2 のC状態に電位が移行し, 基体金属の溶解 がはじまる.放電電流密度 $0.1 \sim 0.2 \mathrm{~A} / \mathrm{cm}^{2}$ の範囲で得 られる電気量は充電に用いた電気量の 90 95\% 程度で あり, 電流損失はさほど大きくはない，電流損失の原因 として金属霧としての電解質への溶解（とくに充電時に 抗こと考えられる)，液体合金の自己放電，さらには 放電時の電極中での濃度分極による利用率の低下などが 考えられる. 放電終了後, さらに低、電流密度で放電を 行い，残存アルカリ金属量を测定し，放電時のアルカリ 金属の利用率を調べると， $0.1 \sim 0.2 \mathrm{~A} / \mathrm{cm}^{2}$ 程度の電流 密度での放電では $95 \%$ 以上のアルカリ金属が放電して いることがわかった. 寸なわち充電電流密度 $0.1 \mathrm{~A} / \mathrm{cm}^{2}$, 放電電流密度 $0.2 \mathrm{~A} / \mathrm{cm}^{2}$ 程度で, この形式の負極を用 いる場合，十分安定した状態で使用できることを示す. この形式の電池では 基体金属の放電がはじると, 電 位が急変するため, 電池放電中, 基体金属のイオン化反 応を防ぐことも装置的に可能である。

\section{2 電流密度ट電位との関係}

充電時の正，負両極での 電流密度と電位との関係索 Fig. 3 に，放電時の関係を Fig. 4 に示した. 正極には 触媒を添加していない多孔質炭素を用いた場合の結果を 示してある. 正極では充電時に比べて放電時の方が分極 が大きく, 放電時, $0.5 \mathrm{~A} / \mathrm{cm}^{2}$ 程度の電流密度で約 0.15 $\mathrm{V}$ の分極を生ずる。負極では放電時アルカリ金属濃度が 小さくなると分極が著しく大きくなるが，アルカリ金風 濃度 10 atomic \% 付近では放電時の方が充電時に比べ 


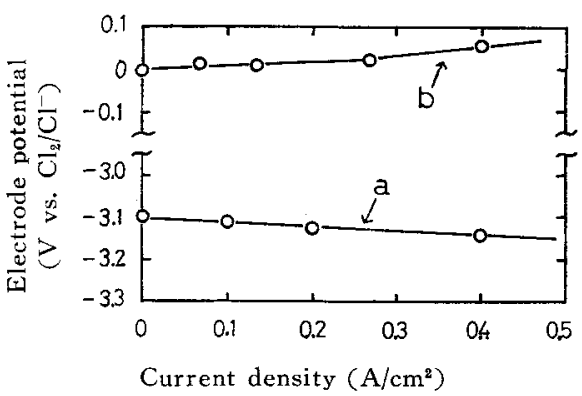

a : At negative electrode of $\mathrm{Zn-Li,K}$ alloy (Li, K 10 atomic \%)

$\mathrm{b}$ : At positive electrode of $\mathrm{Cl}_{2}$ on carbon ${ }^{23}$

Fig. 3 Current-potential relation during charge at steady state of negative and positive electrode in $\mathrm{LiCl}-\mathrm{KCl}$ melt at $450^{\circ} \mathrm{C}$

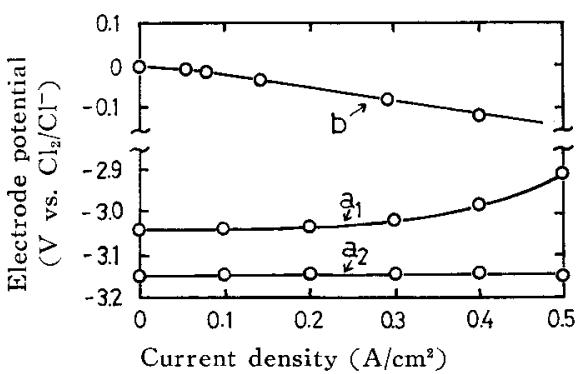

a : At negative electrode of $\mathrm{Zn}-\mathrm{Li}, \mathrm{K}$ alloy

( $a_{1}: \mathrm{Li}, \mathrm{K} 5$ atomic $\%, \mathrm{a}_{2}: \mathrm{Li}, \mathrm{K} 15$ atomic \%)

b : At positive electrode of $\mathrm{Cl}_{2}$ on carbon ${ }^{8}$

Fig. 4 Current-potential relation during discharge at steady state of negative and positive electrode in $\mathrm{LiCl}-\mathrm{KCl}$ melt at $450^{\circ} \mathrm{C}$

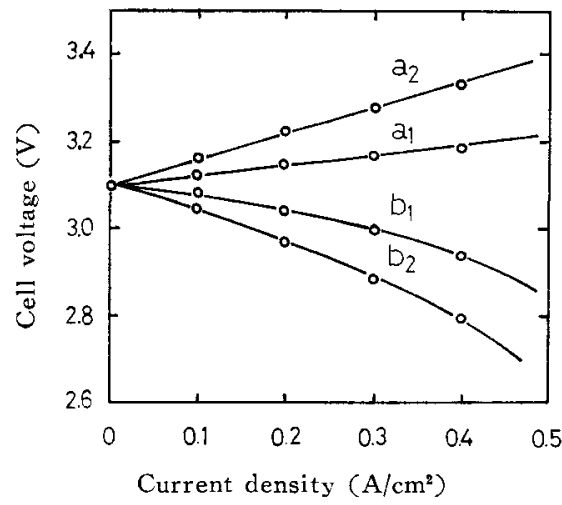

$a_{1}, b_{1}$ : In the case of neglecting ohmic loss in $\mathrm{LiCl}-\mathrm{KCl}$ melt

$a_{2}, b_{2}:$ In the case of assuming $5 \mathrm{~mm}$ distance between electrodes

$a_{1}, a_{2}:$ In the case of charge

$b_{1}, b_{2}$ : In the case of discharge

Fig. 5 Estimation of cell voltage of battery $\mathrm{Li}, \mathrm{K}(\mathrm{Zn}) / \mathrm{LiCl}-\mathrm{KCl} / \mathrm{C} \cdot \mathrm{Cl}_{2}$ at $450^{\circ} \mathrm{C}$
て分極が小さいしたがって高充放電性能を得るために は放電時の分極が小さくなるような正極材質の開発，ま た負極のアルカリ金属濃度が濃い状態で電池を作動させ ることが必要である。 Fig. 3 および 4 を用いて，電池 を組み立てた場合の充放電特性を求めると， Fig. 5 の よ5になる. Fig. 5 の $a_{1}, b_{1}$ は電解質のオ一ム損がな いと仮定した場合の充放電特性であり，0.5 A $/ \mathrm{cm}^{2}$ 程度 の高電流密度放電に拈いても約 $2.8 \mathrm{~V}$ 程度の高い電圧 が得られることがわかる， $a_{2} ， b_{2}$ は極間距離を $5 \mathrm{~mm}$ と 仮定した場合に生ずるオーム損を加味した場合の充放電 特性で，電池を組んだ場合，オーム損が分極に対して大 きい影響を与えることがわかる。したがって電池作動時 の分極を下げるためには極間距離の縮小が大きい課題と なる。

\section{3 負極活物質の自己放電}

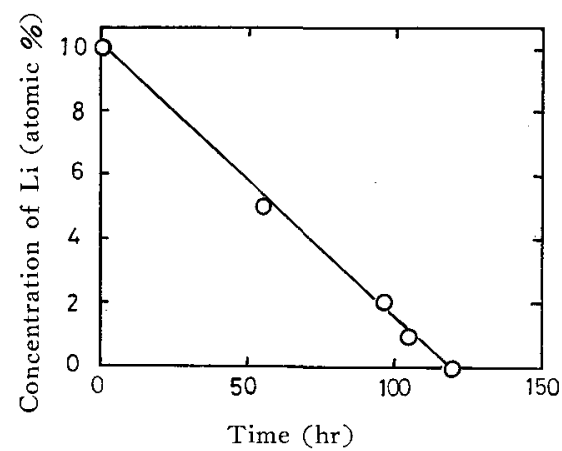

Fig. 6 Self-discharge charactristic of $\mathrm{Li}, \mathrm{K}-\mathrm{Pb}$ alloy in $\mathrm{LiCl}-\mathrm{KCl}$ melt under chlorine atmosphere at $500^{\circ} \mathrm{C}$

塩素を十分溶存させた電解質中での負極活物質の自己 放電速度測定した結果の 1 例を Fig. 6 に示した.リ チウムー鉛合金の場合，リチウムの濃度変化は時間に対 して值線関係を示し, 自己放電反応はりチウム濃度に対 してゼロ次の反応であることがわかる：自己放電はリチ ウムと程素との反応により進行すると考えられるが，こ の結果は塩素の電極面への拡散が律速段階となっている ことを示唆する． Fig. 6 より自己放電速度を算出する と, 約 $1.2 \times 10^{-5} \mathrm{~A} / \mathrm{cm}^{2}$ 程度であり, 自己放電は非常 に小さいことがわかる.

\section{4 負極活物質の固化濃度とその成分}

充電時，負極基体合金上化電解質中のリチウムイオ ン，カリウムイオンが金属として析出し，これが負極内 部一拡散していく。この場合，これらアルカリ金属の基 体合金中一の抬散速度が遅いと，負極表面へこれら金属 が蓄積し，充電時の分極が大きくなると同時に金属霧と してこれらアルカリ金属が電解質中に溶解し好ましくな 、，とくに，合金が固化すると拡散速度は著しく低下す るため, 固化状態洷達するまでの濃度が充電の限界と 

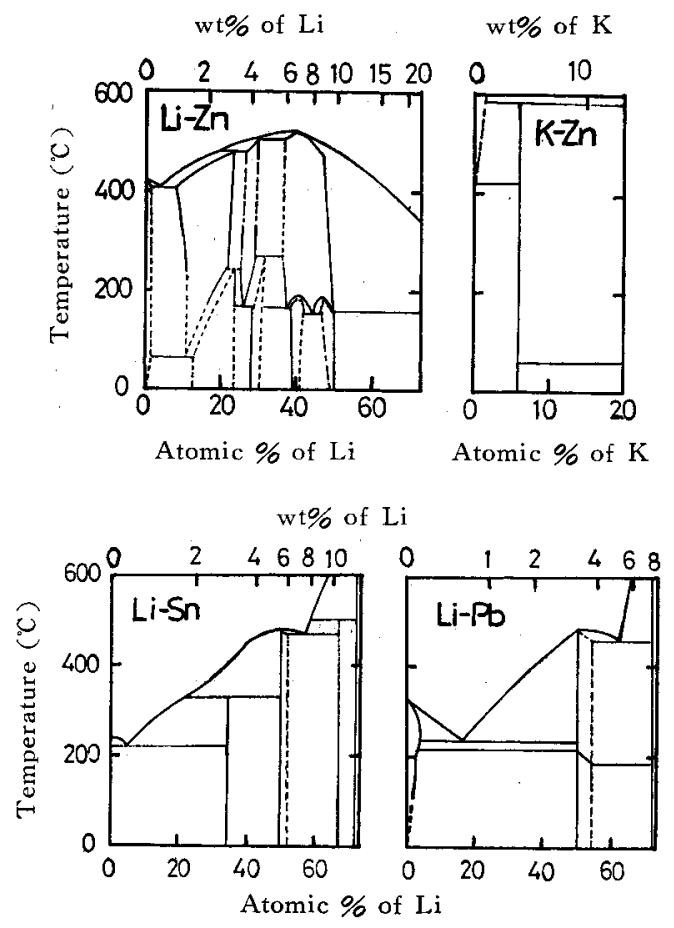

Fig. 7 Phase diagrams of $\mathrm{Li}-\mathrm{Zn}_{\mathrm{n}}, \mathrm{K}-\mathrm{Zn}_{\mathrm{n}}, \mathrm{Li}-\mathrm{Sn}$ and $\mathrm{Li}-\mathrm{Pb}^{4)}$

なる、この濃度が高い方が，単位重量当りの容量效率が 高くなる。この濃度を知るためには，リチウムーカリウ ムー基体合金の三成分系の状態図を作成しなければなら ない.ここでは，Hansen" ${ }^{4}$ の示した二成分系の状態図 を用いて考察する.二成分系状態図の代表例を Fig. 7 に 示した.この図より $450^{\circ} \mathrm{C}, 500^{\circ} \mathrm{C}$ でリチウムが合金を つくる場合の固化濃度を求めると 4.5 で説明する Table

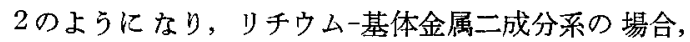
$450^{\circ} \mathrm{C}$ から $500^{\circ} \mathrm{C}$ 一温度を上げるとリチウムの入り得 る量も大幅に堌大寸ることがわかる，atomic\%での固 化状態に至るまでのリチウム濃度はリチウムー鉛合金が 一番大きく, つづいてリチウムースズ合金，リチウムー里 鉛合金の順に小さくなる，電池活物質として比較する場 合は, 負極の単位重量当りのとりだしらる電気量を比較 するのがよい，すなわち重量％で比較するのがよくこ の場合江亜鉛，スズ、鉛で大きい差違はなく, 負極単位 重量当りとりだしらる電気量はいずれの基体金属を用い ても大きい差はないようである．カリウムー基体金属二 成分系に対しては, 基体金属として亜鉛を用いた場合に ついてのみ例として Fig. 7 に示したが，カリウムは亜 鉛中に液状でほとんど溶解しないことがわかる.スズ, 鉛の場合もほとんど同様である，綮密には三成分系状態 図を用いねば正しい考察はできない。この形式の電池で 実験した場合，基体金属に亜鉛を用いた場合， $450^{\circ} \mathrm{C} て ゙$
はアルカリ金属淲度約 15 atomic \%で固化がはじまり， $500^{\circ} \mathrm{C}$ では約 25 atomic \%で固化がはじまった。また 鉛を用いた場合 $450^{\circ} \mathrm{C}$ で約 45 atomic \% で固化がは じまり， $500^{\circ} \mathrm{C}$ では約 50 atomic \%においても固化し なかった. したがってリチウムー基体金属二成分系で得 られる固化濃度に近い状態で実際に注固化がおこってい るものと思われる。

Table 1 Qualitative analysis of depositing metal in substrate metal of negative electrode during charge at $0.1 \mathrm{~A} / \mathrm{cm}^{2}, 450^{\circ} \mathrm{C}$ by JACO emission spectral analysis

\begin{tabular}{c|c|c|c}
\hline $\begin{array}{r}\text { Substrate } \\
\text { metal }\end{array}$ & $\begin{array}{c}\text { Quantity } \\
\text { of charge } \\
\text { (atomic \%) }\end{array}$ & \multicolumn{2}{|c|}{ Depositing metal } \\
\hline $\mathrm{Ln}$ & 0 & - & $\mathrm{Ki}$ \\
\hline $\mathrm{Sn}$ & 7 & ++ & - \\
\hline $\mathrm{Pb}$ & 5 & - & - \\
\hline & 0 & - & \pm \\
\hline
\end{tabular}

つぎに，実際に生成する液体金属合金の成分を調べる 目的で，充電した状態における合金の成分を JACO 発 光分光分析器で分析した. この結果を Table 1 に示し た、充電した液体金属合金中には，それぞれの基体金属 に対して、リチウム，カリウムおよび若于の不純物が検 出された. リチウムおよびカリウムの濃度は正確にはわ からないが，ややリチウムの方が多い上うである。しか しカリウムもかなりの量存在するようであり，これら成 分組成の定量的取扱い, 電池特性に及ぼす影響法今後の 課題である.

\section{5 負極の電池活物質としての特性}

4.4 までに得られた結果に基づいて，負極合金よして リチウムー基体金属合金ができたとして考えた場合の電 池活物質としての特性をまとめると Table 2 のように なる.負極活物質単位重量当り得られる電気量はリチウ ム金属を用いた場合に比べて，リチウム合金を用いた場 合の方が著しく小さい，しかしリチウム金属を用いた場 合，これを保持するための多孔体電極が必要であり， それの重量を加味すると大きい差異はなくなるである う.またこの形式の電池では約 $3.0 \mathrm{~V} の$ 電圧が得ら れ，リチウム金属を用いた場合の約 83\% の起電力を得 ることができる. 出力エネルギー密度は負極 $1 \mathrm{~kg}$ に対 して約 $500 \mathrm{Whr}$ であり, 旧来の鉛電池の出力エネルギ 一密度が約 $50 \mathrm{Whr}$ 程度である点と比べ，大きい出力ェ ネルギー密度が期待できる，実際にこの電池を放電する 場合の特性注 Fig. 5 の $b_{2}$ 曲線で示される. $0.5 \mathrm{~A} / \mathrm{cm}^{2}$ の放電で約 $2.6 \mathrm{~V}$ の電圧が得られ出力密度が $1.3 \mathrm{~W} / \mathrm{cm}^{2}$ $\left(130 \mathrm{~W} / \mathrm{dm}^{2}\right)$ となり, $1 \mathrm{~cm}^{2}$ の電極面積をもつ電池の 
体積を $5 \mathrm{~cm}^{3}$ 程度と仮定すれば， $0.26 \mathrm{~kW} / l$ 程度の出力が 期待で き, 電気自動車として用いるため の最高出力 $150 \mathrm{~kW}$ を維持するた めの電池としては $600 l$ 程度の大 きさでよいことがわかる.これら の点よりこの形式の電池湻出力 密度電池としての期待が大きいも のと思われる.この形式の電池を 実用化するためには，高温の保持， 正極充電時に発生する塩素の貯蔵 などさらに解決しなければならな い点が多い，高温の保持は得られ るエネルギーの一部を熱源として 用いることにより，また塩素の貯 蔵は充電時発生する塩素を傎極多 孔質炭素中に吸蔵させるかるるい は液化して別室に貯蔵するかなどにより解決できるもの と思われる。

\section{5 結 論 (Conclusion)}

電気自動車用電池として溶融塩を用いたリチウム合 金一塩素二次電池を新しく提案し，その可能性を示した. リチウム合金の基体金属として亜鉛，スズ，鉛いずれを 用いても性能上は大きい差異はない，負極にリチウム合 金を用いることにより，リチウム金属を用いる場合と比 ベて電池製作が容易となる.この形式の電池では出力エ ネルギー密度が負極 $1 \mathrm{~kg}$ 当り約 $130 \mathrm{~W}$ と非常に大き く, 高出力エネルギ一密度, 高出力密度電池として十分 期待できる，またりチウム合金の自己放電も 約 $1.2 \times$
Table 2 Performance of Li-Metal alloy electrode at litium-chlorine battery

\begin{tabular}{c|c|c|c|c|c}
\hline \hline \multirow{2}{*}{ Alloy } & $\begin{array}{c}\text { Concentration } \\
\text { of Li }\end{array}$ & $\begin{array}{c}\text { Coulombic } \\
\text { capacity } \\
\text { atomic } \\
(\%)\end{array}$ & $\begin{array}{c}\text { wt } \\
(\%)\end{array}$ & $\begin{array}{c}\text { Electromotive } \\
\text { force at } 450^{\circ} \mathrm{C} \\
(\mathrm{Vh})\end{array}$ & $\begin{array}{c}\text { Output energy } \\
\text { (whr/kg(Li-M)) }\end{array}$ \\
\hline $\mathrm{Li}$ & 100 & 100 & 3890 & 3.6 & 14000 \\
\hline \multirow{5}{*}{$\mathrm{Li}-\mathrm{Zn} \mathrm{n}$} & 10 & 1.2 & 47 & 3.1 & 146 \\
& $10^{*}$ & 1.2 & 47 & 3.1 & 146 \\
& $28^{* *}$ & 4.1 & 159 & & $477^{* * *}$ \\
\hline \multirow{5}{*}{$\mathrm{Li}-\mathrm{Sn}$} & 10 & 0.6 & 23 & 2.8 & 64 \\
& $40^{*}$ & 3.7 & 144 & 2.9 & 417 \\
& $58^{* *}$ & 7.4 & 288 & & $864^{* * *}$ \\
\hline \multirow{5}{*}{$\mathrm{Li}-\mathrm{Pb}$} & 10 & 0.4 & 15 & 3.0 & 45 \\
& $45^{*}$ & 2.6 & 101 & 3.1 & 313 \\
& $63^{* *}$ & 5.4 & 210 & & $630^{* * *}$ \\
\hline
\end{tabular}

* $\mathrm{Li}$ concentration of $\mathrm{Li}-\mathrm{M}$ alloy just before its solidification at $450^{\circ} \mathrm{C}$

** $\mathrm{Li}$ concentration of $\mathrm{Li}-\mathrm{M}$ alloy just before its solidification at $500^{\circ} \mathrm{C}$

*** Estimated in the case that electromotive force is $3.0 \mathrm{~V}$

$10^{-5} \mathrm{~A} / \mathrm{cm}^{2}$ 程度と非常に小さい。

最後に本研究を行うに当って，ご援助いただいた新神戸電機 株式会社に，また JACO 発光分光分析を行うに当ってご便宜 をいただいた京都大学工学部治金学教室 薗田武則氏に謝意を 表する.

(Received Feb. 9, 1971)

\section{女 献}

1) D.A.J. Swinkls, J. Electrochem. Soc. 113,6 (1966); 114, 812 (1967).

D.A.J. Swinkels, S.B. Tricklebank, Electrochem. Technol. 5, 327 (1967).

2）吉沢四郎，竹原善一郎，伊藤靖彦，岡 和吉，本誌 37，762 (1969)。

3) 声沢四郎, 竹原善一郎, 中西洋一, 本誌 35, 225, 294 (1967).

4) M. Hansen, "Constitution of binary alloys", 883, 900, 903, 905 (1958), McGraw-Hill Book Co., New York. 